\title{
Keanekaragaman Jenis Jamur Makroskopis di Hutan Desa Tewah Pupuh Kabupaten Barito Timur
}

\author{
Sri Leluni ${ }^{*}$, Siti Sunariyati ${ }^{2}$, Adventus Panda ${ }^{2}$ \\ ${ }^{1}$ Program Studi Pendidikan Biologi, Fakultas Keguruan dan Ilmu Pendidikan, Universitas Palangka Raya, \\ Kota Palangka Raya, Indonesia \\ 2Program Studi Biologi, Fakultas Matematika dan IImu Pengetahuan Alam, Universitas Palangka Raya, \\ Kota Palangka Raya, Indonesia \\ *email: lelunisri@gmail.com
}

Kata Kuci:

Jamur Makroskopis

Keanekaragaman Jenis

Materi Jamur

Submitted: $29 / 08 / 2020$

Revised: 09/10/2020

Accepted: 01/12/2020
Abstrak. Jamur termasuk sel eukariotik yang tidak memiliki klorofil, tumbuh dari hifa, memiliki dinding sel yang mengandung kitin, bersifat heterotrof, menyerap nutrien melalui dinding selnya, dan mengekresikan enzim ekstraseluler ke lingkungan melalui spora, melakukan reproduksi seksual dan aseksual. Jamur makroskopis adalah jamur yang tubuh buahnya berukuran besar (berukuran 0,6 cm atau lebih besar), struktur reproduktif yang terbentuk untuk menghasilkan dan menyebarkan sporanya. Keberadaan jenis jamur di Hutan Desa Tewah Pupuh Kabupaten Barito Timur masih banyak yang belum diketahui dan tidak dibudidayakan. Kurangnya perhatian pemerintah daerah setempat terhadap keanekaragaman dan pelestarian merupakan alasan penting untuk dilakukannya penelitian. Penelitian ini juga bertujuan untuk mengetahui keanekaragaman jamur Makroskopis di Desa Tewah Pupuh dan diharapkan dapat membantu pembelajaran siswa di Sekolah Menengah atas dalam Materi Keanekaragaman Hayati. Metode yang digunakan dalam penelitian ini adalah metode survei dengan teknik Purposive Sampling untuk menjelajah daerah yang terdapat jenis jamur, yaitu dengan dilakukannya pengumpulan data dengan menyusuri area Hutan Desa Tewah Pupuh dengan total luas area $240 \mathrm{~m}^{2}$. Data yang dikumpulkan adalah jumlah jenis, jumlah individu jenis, dan jumlah kehadiran jenis. Data dianalisis menggunakan Indeks Keanekaragaman Spesies (species diversity), dan Indeks Nilai Penting (INP). Hasil penelitian mendapatkan 16 jenis jamur di Desa Tewah Pupuh, yaitu Lycoperdon pyriforme, Sarcoscypha coccinea, Polyporus sp., Hygrocybe sp., Fomes fomentarius, Mycena overholtsii, Mycena filopes, Thelephora sp., Pleurotus florida, Trametes sp., Cariolus sp., Daedalea sp., Ganoderma sp., Tricholoma sejunctum, Mycena melligena, Microporus sp. Indeks keragaman Jenis ( $\left.\mathrm{H}^{\prime}\right)$ jamur sebesar 2,549. Berdasarkan indikator nilai H', maka tingkat keragaman jenis jamur di Desa Tewah Pupuh Kabupaten Barito Timur termasuk dalam kategori keragaman sedang, yaitu $H^{\prime} 1,5 \leq H \geq 3,5$. Indeks nilai penting (INP) yang tertinggi mencapai 49,938 \% yaitu jenis Mycena melligena, Sedangkan jenis 
jamur dengan indeks nilai penting (INP) yang rendah yaitu, Mycena filopes dengan nilai (INP) 6,699\%.

\section{PENDAHULUAN}

Kalimantan Tengah Merupakan kawasan hutan yang sangat luas dengan tingkat keanekaragaman hayati yang tinggi. Komposisi atau susunan pokok hutan hujan tropis di Indonesia, yang terdiri atas banyak pohon dari berbagai jenis, bentuk, keliling tanah, dan tinggi pohon. Hutan itu sendiri menciptakan iklim dan lingkungan mikro yang didalamnya hidup tumbuhan lain secara berlimpah seperti epifit, tumbuhtumbuhan menjalar (liana), perdu dan herba, serta berbagai jenis hewan dan jamur. Hutan di Kalimantan Tengah merupakan hamparan emas hujan yang indah dan masih asli dengan keanekaragaman hayati yang besar (Mochamad, dkk, 2007).

Berdasarkan letak geografisnya provinsi Kalimantan Tengah berada diantara 0045' LU dan 3030' LS dan 1110BT dan 1160 BT. Memiliki iklim tropis yang lembab dan panas suhu udara berkisar antara 21-310 C dan curah hujan terbesar sepanjang tahun. Pada keadaan normal musim hujan terjadi pada bulan Oktober sampai Desember dan Januari sampai Mei, sedangkan musim kemarau bulan Juni sampai Agustus. Presentasi wilayah hutan yang besar, menyebabkan Kalimantan Tengah kaya akan berbagai macam vegetasi tropis, termasuk jamur yang keanekaragamannya cukup tinggi.

Jamur atau fungi adalah sel eukariotik tidak memiliki klorofil, tumbuh sebagai hifa, memiliki dinding sel yang mengandung kitin, bersifat heterotrof, menyerap nutrien melalui dinding selnya, dan mengekresikan enzimenzim ekstraseluler ke lingkungan melalui spora, melakukan reproduksi seksual dan aseksual. Jamur makroskopis atau cendawan adalah jamur-jamur yang tubuh buahnya berukuran besar (berukuran 0,6 $\mathrm{cm}$ dan lebih besar) yang merupakan struktur reproduktif yang terbentuk untuk menghasilkan dan menyebarkan sporanya. (Gandjar 2006). Jamur merupakan salah satu keunikan yang memperkaya keanekaragaman jenis mahkluk hidup. Beberapa jenis jamur telah banyak dimanfaatkan oleh manusia sebagai bahan makanan dan sumber bahan obat-obatan tradisional maupun modern. Jamur memegang peranan penting dalam kehidupan masyarakat, karna beberapa jamur banyak sekali manfaatnya. Selain nilai gizi cukup tinggi, jamur juga mempunyai khasiat sebagai obat. (Gendres dalam Sulastri, 2015).

Jamur di alam beranekaragam jenisnya, baik yang berukuran makroskopis maupun yang berukuran mikroskopis. Jamur merupakan organisme yang berperanan penting dalam membusukkan atau menghancurkan sisa-sisa tumbuhan maupun hewan, sehingga jamur dapat hidup secara saprofit pada sisa-sisa organisme dan parasit pada organisme hidup (Melisa, 2012). Secara alami jamur dapat tumbuh pada musim tertentu dalam satu tahun. Hal ini terjadi karena ketergantungan hidupnya akan temperatur dan kelembaban tertentu. Pada umumnya yang tepat untuk berburu jamur di alam bebas adalah pada saat musim hujan untuk daerah tropika (Melisa, 2012).

Keberadaan jenis jamur di Hutan Desa Tewah Pupuh Kabupaten Barito Timur 
masih banyak yang belum di ketahui dan tidak dibudidayakan. Berdasarkan hasil observasi yang dilakukan, ada beberapa aktivitas masyarakat di Desa Tewah Pupuh salah satunya membuka lahan untuk berladang. Aktivitas masyarakat berladang ini menyebabkan beberapa hal salah satunya menebangan pohon untuk keperluan pembukaan lahan baru. Hasil dari penebangan pohon itu beberapa pohonnya tidak diambil, dan dibiarkan begitu saja, sehingga lama kelamaan pohon tersebut menjadi lapuk dan hal ini berpotensi sebagai tempat hidup jamur. Oleh karena itu peneliti tertarik untuk meneliti keanekaragaman jenis jamur, hasil yang diharapkan dari peneliti adalah untuk memberikan informasi keanekaragaman jenis jamur serta dapat menjadi pansduan untuk pengenalan jenis-jenis jamur sebagai informasi awal yang dapat meningkatkan kesejahteraan masyarakat dan tetap menjaga kelestarian keanekaragaman jamur dari ancaman menurunnya keanekaragaman hingga ancaman kepunahan, baik secara alami maupun disebabkan oleh aktivitas manusia.

Berdasarkan Kurikulum K13 Materi Jamur di SMA K13 kelas X Mata Pelajaran Biologi SMA jilid IA semester 1 dengan materi jamur, fokus kajian pada materi jamur adalah Menyajikan data hasil pengamatan ciri-ciri dan peran jamur dalam kehidupan dan lingkungan dalam bentuk laporan tertulis.

Penelitian di lakukan oleh Ratmiati (2016), Tentang Inventarisasi Jamur Makroskopis di Daerah Perkebunan Karet Desa Baamang Hulu Kabupaten Kota Waringin Timur. Berdasarkan hasil penelitian menunjukan bahwa jamur makroskopis di area penelitian terdiri dari 10 (sepuluh) spesies, 8 (delapan) genus dan 6 (enam) family. Kesepuluh spesies tersebut adalah Gymnopus sp., Pycnoporus sp., Trametes sp. Polyporus brumalis, Mycena melligena, Mycena filofes, Schizophyllum sp, Hygrocybe ceracea, Hygrocybe cantharellus, dan Dacryopinax spathularia. Anggota family Polyporaceae adalah spesies yang paling banyak di temukan.

Penelitian dilakukan oleh Triana (2015), Tentang Inventarisai Jamur Makroskopis Kelas Basidiomycetes di Desa Muara Tupuh Kecamatan Laung Tuhup Kabupaten Murung Raya untuk Menunjang Materi Jamur di SMA. Berdasarkan hasil penelitian menunjukkan jamur makroskopis di area penelitian terdiri dari 21 (dua puluh satu) spesies yaitu: Microporus sp., Daedalea sp., Panus sp., Fomes fomentarius, Coriolus sp., Polyporus sp., Coltricia cinnamomea, Pyknoporus sangunis, Ganoderma sp, Thelephora sp., Cantharells, Amanita sp.1, Amanita sp.2, Schyzophyllum commune, Pleurotus florida, Stropharia aeruginosa, Hygrocybe sp.1, Hygrocybe sp.2, Hygrocybe sp.3, Phallus indusiatus, Auricularia polytricha.

Penelitian dilakukan oleh Aprianti Yenti, 2017. Tentang Inventarisai Jenis-Jenis Jamur makroskopis di Desa Buntut Bali Kecamatan Pulau Malan Kabupaten Katingan Sebagai Penunjang Materi di SMA. Berdasarkan hasil penelitian menunjukan jamur makroskopis di area penelitian diperoleh 10 (sepuluh) jenis jamur makroskopis, yaitu Sarcoscypha coccine, Auricularia auricular-judea, Hygrocybe cantharellus, Gymnopus sp., Marasmiellus sp., Dacryopinax spathhularia, Schizophyllum sp., Pycnoporus sp., Tremetes gibbosa, Microporus sp. Jumlah jamur mskroskopis di wilayah kebun pisang paling banyak 8 (delapan) jenis, hanya terdapat 2 (dua) jenis di wilayah kebun karet. Jenis jamur yang dapat dikonsumsi dari hasil inventarisasi adalah jamur 
Auricularia auricular-judea dan jamur Schizophyllum sp. sedangkan untuk delapan jamur yang didapatkan merupakan jamur yang tidak dapat dikonsumsi. Penelitian ini dimanfaatkan sebagai penunjang materi Jamur di SMA dalam bentuk booklet.

Penelitian dilakukan oleh Rusdiana, Irma. (2016), Tentang Inventarisai JenisJenis Jamur Makroskopis di Desa Pujon Kecamatan Kapuas Tengah Kabupaten Kapuas Sebagai Penunjang Materi Jamur di SMA. Berdasarkan hasil penelitian menunjukan jamur makroskopis di area penelitian diperoleh 19 (sembilan belas) jenis jamur makroskopis Penelitian ini dimanfaatkan sebagai penunjang materi Jamur di SMA dalam bentuk booklet. Penelitian dilakukan oleh Sari (2015), Tentang Inventarisai Jamur Basidiomycetes di Kelurahan Menteng Kota Palangka Raya Sebagai Penunjang Materi Keanekaragaman Haytai di SMA. Berdasarkan hasil penelitian menunjukan jamur makroskopis di area penelitian diperoleh 34 (tiga puluh empat) spesies jamur kelas Basidiomycetes yang terdiri dari 5 (lima) ordo, 17 (tujuh belas) famili. Jamur dari ordo Aphylloporales paling banyak ditemukan di Kelurahan Menteng kota Palangka Raya.

Selain itu, hasil penelitian ini akan dijadikan sumber informasi yang berguna bagi siswa SMA dalam mempelajari materi jamur di sekolah. Kendala dalam penyampaian materi Keanekaragaman Hayati khususnya keanekaragaman jenis jamur antara lain masih kurangnya bukubuku penunjang, sehingga pemahaman siswa mengenai

Keanekaragaman Hayati di daerahnya sendiri masih kurang. Jamur merupakan salah satu penyusun Keanekaragaman Hayati di hutan Kalimantan Tengah.
Sehingga hasil penelitian ini diharapkan dapat menjadi salah satu alternatif untuk membantu para pendidik dalam menambah sumber belajar pada materi keanekaragaman hayati.

\section{METODE}

Jenis penelitian yang dilakukan adalah penelitian deskriptif kuantitatif yaitu penelitian dengan teknik survey cara yang dilakukan yaitu dengan mendeskripsikan jenis jamur yang ada di hutan Desa Tewah Pupuh dan dilakukan pencatatan dan menganalisis data hasil penelitian menggunakan metode analisis vegetasi (kerapatan, frekuensi, indek keanekaragaman dan indeks nilai penting).

Lokasi penelitian adalah di Hutan Desa Tewah Pupuh. Subjek penelitian adalah jamur. Waktu penelitian di laksanakan pada bulan Maret sampai pada bulan Mei 2019.

Sumber data berupa data primer karena data yang diperoleh secara langsung dari sumber asli tidak melalui media perantara. Sumber data primer ini dilakukan pada 3 tempat pengambilan sampel di Hutan Desa Tewah Pupuh dengan dilakukan pengambilan sampel jamur serta melihat kondisi hutan. Dimana peneliti melakukan survei, dokumentasi lokasi penelitian.

Populasi dalam penelitian ini adalah seluruh jenis jamur Makroskopis di Hutan Desa Tewah Pupuh Kabupaten Barito Timur. Sampel adalah jenis jamur Makroskopis yang berhasil ditemukan di lokasi hutan Desa Tewah Pupuh.

\section{HASIL DAN PEMBAHASAN}

Hasil penelitian yang telah di lakukan pada wilayah Desa Tewah Pupuh Kabupaten Barito Timur di temukan 16 jenis jamur, yaitu Lycoperdon pyriforme, Sarcoscypha coccinea, Polyporus sp., 
Hygrocybe sp., Fomes fomentarius, Mycena overholtsii, Mycena filopes, Thelephora sp., Pleurotus florida, Trametes sp., Cariolus sp., Daedalea sp., Ganoderma sp., Tricholoma sejunctum, Mycena melligena, Microporus sp.

Penelusuran dilakukan dari 1 plot sampai plot 15 , dengan total jarak yang ditelusuri untuk pengambilan data adalah 100 m. Hasil Pengamatan di lokasi penelitian dengan menyusuri dua area, yaitu area teduh dan area terbuka dengan panjang jelajah $240.000 \mathrm{~m}^{2}$, dari hasil penelitian di temukan 16 jenis jamur, yaitu Lycoperdon pyriforme, Sarcoscypha coccinea, Polyporus sp., Hygrocybe sp., Fomes fomentarius, Mycena overholtsii, Mycena filopes, Thelephora sp., Pleurotus florida , Trametes sp., Cariolus sp., Daedalea sp., Ganoderma sp., Tricholoma sejunctum, Mycena melligena, Microporus $\mathrm{sp}$. Jenis jamur tersebut ditemukan secara langsung.

Area teduh ditemukan 8 jenis jamur yang terdiri dari 110 individu, yaitu Hygrocybe sp., Mycena overholtsii, Mycena filopes, Thelephora sp., Pleurotus florida, Trametes sp., Cariolus sp., Daedalea sp., Sedangkan pada area terbuka terdapat 8 jenis jamur yang terdiri dari 142 individu, yaitu Lycoperdon pyriforme, Sarcoscypha coccinea, Polyporus sp., Fomes fomentarius, Ganoderma sp., Tricholoma sejunctum, Mycena melligena, Microporus $\mathrm{sp}$.

Hasil perhitungan Indeks Keragaman Jenis diperoleh 2,549. Hal ini berarti nilai indeks keragaman jenis jamur pada semua sub lokasi area teduh dan terbuka termasuk dalam kriteria $H^{\prime} 1,5 \leq H^{\prime} \geq 3,5$ atau keanekaragaman jenis jamur di wilayah Desa Tewah Pupuh termasuk dalam kategori sedang, karena penyebaran jamur yang tidak merata, ada jenis tertentu yang dapat ditemukan dalam jumlah yang sangat banyak namun ada spesies tertentu yang hanya ditemukan sedikit. Karena dipengaruhi oleh beberapa faktor. Faktor alam yang mempengaruhi jumlah jamur di alam antara lain suhu, $\mathrm{pH}$, dan kelembaban. Hal ini terjadi karena ketergantungan hidupnya akan temperatur dan kelembaban tertentu.

Pada umumnya yang tepat untuk berburu jamur di alam bebas adalah pada saat musim hujan untuk daerah tropika (Melisa, 2012).

Indeks Keanekaragaman ShannonWienner $\left(\mathrm{H}^{\prime}\right)$ merupakan ciri tingkat komunitas berdasarkan organisasi biologinya. Keanekaragaman spesies dapat digunakan untuk mengukur stabilitas komunitas, yaitu kemampuan suatu komunitas untuk menjaga dirinya tetap stabil meskipun ada gangguan terhadap komponen-komponennya. (Soegianto, 1994 dalam Indriyanto, 2006).

Indeks nilai penting (INP) adalah untuk melihat seberapa besar peran suatu tumbuhan dalam ekosistem. Indeks Nilai Penting (INP) digunakan untuk menggambarkan tingkat penguasaan yang diberikan oleh suatu spesies terhadap komunitas, semakin besar nilai INP suatu spesies semakin besar tingkat penguasaan terhadap komunitas dan sebaliknya. (Soegianto, 1994). Berdasarkan hasil penelitian bahwa jenis jamur Mycena melligena mempunyai peranan sangat tinggi pada area terbuka dibandingkan jenis jamur lainnya. Dalam penelitian ini terbagi dalam dua tempat, yaitu area tempat teduh dan area tempat terbuka. Area tempat teduh yang berarti area yang agak kurang cahaya matahari. Sedangkan area tempat terbuka ialah area yang intensitas cahaya matahari nya penuh. 
Dari keenambelas jamur yang berhasil diidentifikasi di lokasi penelitian merupakan jenis yang paling sering ditemukan, dan jamur yang memiliki indeks nilai penting (INP) yang tertinggi mencapai 49,930\% yaitu Mycena melligena.

Mycena melligena, merupakan jenis jamur yang paling banyak ditemukan menggerombol dalam kelompok dengan 80111 individu, habitat jamur ini tumbuh pada kayu lapuk, dan di tempat terbuka. Tingginya nilai penting (INP) untuk jenis Mycena melligena karena dilokasi penelitian Mycena melligena memiliki jumlah individu yang paling banyak dibandingkan jumlah individu dari 15 jenis jamur lainnya, baik pada area teduh maupun area terbuka, sebagaimana terlihat pada tabel 6 dimana individu dari jenis Mycena melligena bisa dijumpai pada 15 plot pengamatan, yaitu pada area terbuka. Hal ini menunjukkan bahwa jenis Mycena melligena mampu beradaptasi pada berbagai kondisi di wilayah penelitian. Tingginya nilai INP dari jenis Mycena melligena yaitu dikarenakan jamur jenis ini mampu beradaptasi pada habitat dengan intensitas cahaya matahari penuh (area terbuka) dan pada habitat yang agak kurang cahaya matahari (area teduh).

\section{KESIMPULAN}

Berdasarkan hasil penelitian dan pembahasan. Dapat disimpulkan bahwa ditemukan 16 jenis jamur yang terdapat di Desa Tewah Pupuh Kabupaten Barito Timur (Area Teduh dan Terbuka), Yaitu : Lycoperdon pyriforme, Sarcoscypha coccinea, Polyporus sp., Hygrocybe sp., Fomes fomentarius, Mycena overholtsii, Mycena filopes, Thelephora sp., Pleurotus florida, Trametes sp., Cariolus sp., Daedalea sp., Ganoderma sp., Tricholoma sejunctum, Mycena melligena, Microporus sp. Berdasarkan jumlah temuan, jenis
Mycena melligena yang paling banyak ditemui selama pengamatan berlangsung. Indeks keragaman jenis jamur di Desa Tewah Pupuh Kabupaten Barito Timur adalah 2,549. Hasil penelitian keanekaragaman jamur di wilayah Desa Tewah Pupuh Kabupaten Barito Timur sebagai sumber belajar biologi akan diajarkan bahan belajar berupa Booklet.

\section{Referensi}

Alexoolus, C.J 1962. Introduction Mycology (Second Edition). New York. Jhon Wiley \& Sons, Inc. London.

Apriyanti, Y. 2017. Tentang Inventarisasi Jenis-jenis Jamur Makroskopis di Desa Buntut Bali Kecamatan Pulau Malan Kabupaten Katingan Sebagai Penunjang Materi Jamur di SMA. Skripsi. Universitas Palangka Raya. Palangka Raya.

Bibi, F. And Z. Ali. 2013. Measurement Of Diversity Indices Of Avian Communities At Taunsa Barrage Wildlife Sanctuary, Pakistan. 23 (2) : 469-474.

Dwidjosoeputro, D.1978. Pengantar Mikologi. Malang. Alumni.

Fachrul, M.F. 2006. Metode Sampling Bioteknologi. Jakarta: Bumi Aksara.

Gandjar, I. et al. 2006. Pengenalan Kapang Tropik Umum. Jakarta: Yayasan Obor Indonesia UI

Indriyanto. 2006. Ekologi Hutan. Jakarta: Bumi Aksara.

Indrawati, G,R., Wellyzar, S., dan Ariyanti, O., 2006. Mikologi : Dasar Dan Terapan. 
Kountur, R. 2009. Metode Penelitian Untuk Penulisan Skripsi Dan Tesis. Jakarta: PPM.

Mochamad, dkk, 2007. Letak Geografis Provinsi Kalimantan Tengah.

Melisa, 2012. Keragaman Jenis Jamur dan Manfaatnya Bagi Kehidupan. Malang Universitas

$$
\begin{aligned}
& \text { Muhammadiyah Malang. } \\
& \text { Diambil dari }
\end{aligned}
$$

http://aguskrisnoblog.wordpress.com/2012/0 5/09/keragaman-jenis-jamurdanmanfaatnya-bagi-kehidupan/ (diakses 3 November 2017)

Odum, E. P. 1996. Dasar-dasar Ekologi. Terjemahan Tjahjono Samingan Yogyakarta: Gadjah Mada University Press.

Rusdiana, Irma, 2016. Inventarisasi Jenisjenis Jamur Makroskopis di Desa Pujon Kecamatan Kapuas Tengah Kabupaten Kapuas Sebagai Penunjang Materi Jamur di SMA. Skripsi. Universitas Palangka Raya. Palangka Raya.

Ratmiati. 2016. Inventarisasi Jamur Makroskopis di Daerah Perkebunan Karet Desa Baamang Hulu Kabupaten Kota Waringin Barat. Skripsi. Universitas Palangka Raya. Palangka Raya.

Sulastri. 2015. Inventarisasi Jamur Basidiocymetes yang dapat dikonsumsi Masyarakat di Desa Sukaraja Kecamatan Sukamara Kalimantan Tengah Sebagai Penunjang Materi Jamur di SMA. Skripsi. Universitas Palangka Raya. Palangka Raya.
Sastrahidayat, Ika Rochjatun. 2011. Mikologi Ilmu Jamur. Malang. Universitas Brawijaya Press.

Suriawiria.Unus. 2002. Budidaya Jamur Tiram.Yogyakarta. Kanisus

Suhardiman, P. 1989. Jamur kayu. Jakarta. Penebar Swadaya

Samsuri, Sulastri, 2015. Struktur Jamur, Reproduksi Jamur, Identifikasi Jamur, Mikoriza, Lumut Kerak. Skripsi. Universitas Palangka Raya. Palangka Raya.

Sari, D, P 2015. Inventarisasi Jamur Basidiomycetes di Kelurahan Menteng Kota Palangkaraya Sebagai Penunjang Materi Jamur di SMA Dalam Bentuk Bookle. Skripsi. Universitas Palangka Raya. Palangka Raya.

Triana. 2015. Inventarisasi Jamur Makroskopis Kelas Basidiomycetes di Desa Muara Tapuh Kabupaten Murung Raya Untuk Penunjang Materi Jamur di SMA. Skripsi. Universitas Palangka Raya. Palangka Raya.

Tjitrosoepomo. 1998. Morfologi dari Jamur Basidiomycetes. Jakarta

Zoberi, M. H. 1972. Tropical Macrofungi. The Macmillan Press Ltd. London and Basingstoke.

Yuwani, S.H., Irham dan Jamhari. 2014. "Analisis Kelayakan dan Strategi Pengembangan Usaha Budidaya Ikan Air Tawar di Kabupaten Sleman" Agro Ekonomi 25 (2) : 135-143 